\title{
TÕLKIMISEST EUROOPA LIIDU INSTITUTSIOONIDES
}

\author{
HEIKI PISUKE
}

A astal 2118 võiks olla konverentsiteeside algus tõenäoliselt selline: „Kristian Jaak Petersoni 1818. aastal püstitatud visioonini jõudmiseks („kas siis selle maa keel”) kulus ligi kaks sajandit. XX sajandil sai eesti keelest iseseisva riigi riigikeel. Eesti Vabariik oli alates 1921. aastast Rahvasteliidu liige. Eesti kuulus mittevabatahtlikult NSV Liitu (1940-1941; 1944-1991), kuid ka riigikaotuse perioodil toimus ulatuslik tõlkimine teistesse NSVL-i rahvaste keeltesse ja keeltest.

XXI sajandil väljus eesti keele ametlik kasutusala esmakordselt ajaloos emamaa piiridest. See toimus Euroopa Liiduga (EL) ühinemisel 2004. aastal. Eesti keelest sai üks EL-i ametlik keel. Selle sajandi esimese veerandi jooksul kindlustus eesti keele staatus maailmas, seda eeskätt tõlkimise vahendusel. XXI sajandi algusest oli Eesti rohkem kui 150 rahvusvahelise organisatsiooni liige. Liikmelisus võimaldas vajadusel eestikeelset suhtlemist ja eesti kultuuri tutvustamist tõlkimise vahendusel.

XXI sajandi esimesel poolel muutus oluliselt traditsioonilise tõlkija ja tõlgi staatus, kuna tõlkimise põhifunktsioonid läksid üle esmalt masintõlkele, hiljem tehisintellektile. Tõlkijast sai toimetaja, laiemas plaanis aga kultuuri- ja informatsiooni vahendaja, kelle töö põhifunktsioon on kommunikatsioon.

XXI sajandi keskpaigast alates tõlgiti ulatuslikult, kasutades neuroproteese ja aju implantaate. Alates XXI sajandi lõpust toimub „tõlkimine” mõtte jõul, võõrkeelest arusaamine ja enda võõrkeeles väljendamine on XXII sajandil inimaju üks funktsioone. Traditsiooniline tõlkimine, nagu seda mõisteti kuni XXI sajandi alguseni, on marginaalne ja see kuulub pigem kõrgkultuuri."

Mõtelda on mõnus, nagu on ütelnud Hando Runnel, fantaseerida veelgi mõnusam. Igasuguse tulevikufantaasia juured on tänases reaalsuses. Siinse artikli ülesandeks on uurida, mida on andnud ja annab Euroopa Liidu liikmelisus eesti tõlkepraktikale ja -teooriale. See on rohkem kui kümme aastat Euroopa Liidu Nõukogu ja Euroopa Komisjoni (edaspidi vastavalt nõukogu ja komisjon) eesti tõlkeosakondi juhtinud tõlketööstuse administraatori ja õigusteadlase kogemus ja nägemus (vt ka Ilja 2011; Dreving 2014; Pisuke 2013, 2015; Teras 2017).

Artikli uurimisobjektiks on EL-i institutsioonides tehtav kirjalik tõlge. Tõlkija (ingl translator) ja (suuline) tõlk (ingl interpreter) on sisuliselt, õiguslikult ja organisatsiooniliselt erinevad erialad, mille tööprotsess ja probleemid on erinevad. ${ }^{1}$ Suulise tõlke küsimusi EL-i institutsioonides ja nende muutuvat rolli XXI sajandi tõlketööstuses selles artiklis ei käsitleta.

${ }^{1}$ Vandetõlgi seaduses (RT I, 23.12.2013, 1) kasutatav termin vandetõlk on eksitav. Seadus reguleerib tegelikult vandetõlkija tegevust. Seaduse ingliskeelne tõlge (Sworn Translators Act) on korrektne. https://www.riigiteataja.ee/en/eli/527122013001/consolide 
Artiklis keskendun järgmistele teemadele: 1) EL-i mitmekeelsuspoliitika mõju eesti keelele; 2) tõlkimise roll mitmekeelsuspoliitikas, sh tõlkimine kui lahutamatu osa EL-i õigusloomest; 3) tööstuslik tõlkimine ja tõlketööstus; 4) tõlkija rolli muutumine.

\section{„Euroopa keel on tõlkimine” (Umberto Eco)}

Euroopa Liidu keelepoliitika on andnud eesti keelele sellise staatuse, mida sel pole olnud kunagi varem. Eesti keel on rohkem kui 500-miljonilise ühenduse üks ametlikke keeli (nõukogu määrus nr 1, 15. IV 1958). Euroopa Komisjoni mitmekeelsuspoliitika (ingl multilingualism) seadis kolm eesmärki: 1) ergutada keeleõpet ja edendada ühiskonna keelelist mitmekesisust, 2) edendada tugevat mitmekeelset majandust ja 3) muuta EL-i õigusaktid, menetlused ja teave kodanikele nende omas keeles kättesaadavaks (Uus mitmekeelsuse raamstrateegia: 3 ).

Ametliku keele staatus väljendub eesti keele kasutamise võimalustes, eriti selgelt aga tõlkimises. Kõik olulisemad EL-i dokumendid tõlgitakse eesti keelde võrdsetel alustel kõigi teiste EL-i ametlike keeltega, mida 2018. aastal oli kokku 24. Eesti keel on iga päev nähtav, kuuldav ja kasutatav Brüsselis, Luxembourgis, Strasbourgis jm Euroopas, kus kogunevad komisjoni ja nõukogu töögrupid ning toimuvad Euroopa Parlamendi (edaspidi: parlamendi) istungid jm üleeuroopalised kohtumised. Eesti keele kasutamine kodanike ja organisatsioonide ametliku asjaajamiskeelena, võimalus saada oma emakeeles infot ja tutvuda kõigi olulisemate liidu toimimise dokumentidega on õigused, mida Eesti varasem ajalugu ei tunne. ${ }^{2}$

Õigusteooria üks põhimõtteid on, et õigustele vastavad alati kohustused. Mitmekeelsuspoliitikast tulenevaks kohustuseks on tõlkida eesti keelde kõik EL-i õigusaktid ja tähtsaimad poliitilised, majandus-, rahandus-, sotsiaal- ja infodokumendid (edaspidi: eurotekstid). Liikmesriigid on vastu võtnud poliitilise otsuse, millised dokumendid tõlgitakse EL-i ametlikesse keeltesse. Liikmesriigil ega mis tahes muul füüsilisel või juriidilisel isikul pole reeglina õigust sellisest tõlkimisest keelduda või seda takistada. Seega võib EL-i mitmekeelsuse põhimõtet nimetada ka kohustavaks mitmekeelsuseks.

„Emakeelne Euroopa Liit” ei lähe Eesti inimestele palju maksma. Kõik tõlkimisega seotud kulud tasutakse EL-i ühisest eelarvest ja tõlkimine toimub EL-i institutsioonides, mitte liikmesriikides. Kirjalikule ja suulisele tõlkimisele kulub vähem kui $1 \%$ EL-i aastasest eelarvest ja kulu iga liidu kodaniku kohta on umbes kaks eurot aastas (Pisuke 2015: 2).

Tõlkimine kõigisse ametlikesse keeltesse toimub EL-i institutsioonides Brüsselis, Luxembourgis ja Frankfurdis nende institutsioonide enda kehtestatud reeglite alusel. EL-i institutsioonid on oma tegevuses iseseisvad ja liikmes-

2 2018. aasta juulis algatas Euroopa Ombudsman avaliku konsultatsiooni „Keelte kasutamine EL-i institutsioonides, asutustes, büroodes ja ametites” eesmärgiga „edendada arutelu, kuidas ELi institutsioonid saaksid kõige paremini avalikkusega suhelda, nii et valitseks sobiv tasakaal ühelt poolt keelelise mitmekesisuse austamise ja toetamise vajaduse ning teisalt halduslike ja eelarvepiirangute vahel". https://www.ombudsman.europa.eu/et/ correspondence/et/99005 
riikidest sõltumatud. Samal ajal peavad nad oma missiooniks tagada rahvuskeelte areng. Näiteks Euroopa Komisjoni kirjaliku tõlke peadirektoraadi (DGT, Directorate General for Translation) 2016. aasta aruandes on öeldud: „DGT missioon on olla täieõiguslik partner EL-i õigusloome- ja suhtlusprotessis, [---] ning ühtlasi kaasa aidata EL-i iga ametliku keele arendamisele" (DGT Annual Activity Report 2016: 3).

Kuivõrd on Euroopa Liidu reeglid kooskõlas eesti keele arendamise huvidega? Millised on võimalikud riskid ja probleemid? Sama küsimuse saab esitada kõigi ametlike keelte kohta, kuigi nn suurte ja väikeste keelte huvid on erinevad. Eurotekstide suur mass avaldab kindlasti mõju kõigile ametlikele keeltele. Kuid samal ajal on EL-i mitmekeelsuse põhimõte eesti keele säilimise ja arengu garantiiks, vähemalt sel ajal, mil me oleme selle liidu liikmed. Eesti keel on koos teiste suurte ja väikeste keeltega sama staatusega ja ühtemoodi nähtav. Liikmesriigid saavad võrdselt tõstatada keelte ja tõlkimisega seotud poliitilisi küsimusi ja vajadusel algatada õigusaktide muutmist.

Eesti keele kvaliteetse kasutamise lisatagatisena saame vaadelda neid tõlkijaid, kes EL-i institutsioonides tõlgivad eurotekste eesti keelde. Need on valdavalt meie enda tõlkijad, kes on lõpetanud Eestis ülikooli ja saanud Eestis ka oma esimese praktilise tõlkekogemuse. Tõlkijate valik on valdavalt toimunud Euroopa Personalivaliku Ameti (EPSO, European Personnel Selection Office) kaudu võistleval põhimõttel. ${ }^{3}$ Seega on Eesti tõlketiim EL-is just nii tugev, kui me oleme selle suutnud ja tulevikus suudame Eestis ette valmistada ja seda täiendavalt koolitada. Kas eesti rahvas on sellist mitmekeelsust tahtnud? Jah, see on esindusdemokraatia tulemus, mis vormistati õiguslikult rahvahääletusega Euroopa Liiduga liitumise küsimuses 14. septembril 2003. ${ }^{4}$

\section{Tööstuslik tõlkimine ja tõlketööstus}

Tõlkija elukutset on alates tema kaitsepühaku Hieronymuse aegadest (347420) peetud nn autorsuse romantilise kontseptsiooni üheks parimaks näiteks. Romantilist tõlkimist, ${ }^{5}$ kus üks või mõned tõlkijad teevad algusest lõpuni kogu tõlketöö, peetakse ka tänapäeval normiks ilukirjanduse ja luule alal. Traditsiooniline tõlketeooria on üles ehitatud just ajaloolis-romantilise tõlkimise pikaaegsele kogemusele ja põhimõtetele. EL-i institutsioonides toimub tööstuslik tõlkimine. See on sisemiselt korrastatud staadiumidega protsess, mis

${ }^{3}$ Vt https://epso.europa.eu/home_et

${ }^{4}$ Vt Riigikogu 2002. aasta 18. detsembri otsus „Rahvahääletuse korraldamine Euroopa Liiduga ühinemise ja Eesti Vabariigi põhiseaduse täiendamise küsimuses” (RT I 2002, 107, 637) ja Vabariigi Valimiskomisjoni otsus 5. detsembrist 2003 „Rahvahääletuse tulemuste kinnitamine.” (RT I 2003, 63, 426, vt https://www.riigiteataja.ee/akt/630398)

${ }^{5}$ Kasutan seda terminit, tuginedes oma varasemale uurimistööle autoriõiguse alal, kui kuulusin 1990. aastate alguses uurimisrühma, mis uuris autori olemust filosoofias ja õigusteaduses ning võttis vastu Bellagio deklaratsiooni. Nn romantiline autorsuse kontseptsioon (ingl romantic concept of authorship) eristab üksikautorsust tänapäevasest kollektiivsest loomingust paljudes uuemates loometegevuse valdkondades. Vt http://college. cengage.com/english/amore/demo/ch5_r2.html ja https://en.wikipedia.org/wiki/Bellagio_ declaration 
võimaldab toota tõlkeid tööstuslikus ulatuses ja tööstusele omaste meetoditega.

Kui liita kokku EL-i institutsioonide tõlketeenistuste toodang, siis on EL-i aastane tõlkemaht liikmesriikide keeltesse mõõdetav miljonite lehekülgedega. 2017. aastal tõlgiti Euroopa Komisjonis ametlikesse keeltesse üle 2 miljoni ja 2018. aastal ligi 2,2 miljonit lehekülge EL-i dokumente jm tekste (1 lehekülg = 1500 tähemärki). Rekordaastatel on komisjoni tõlkemaht kõigisse keeltesse olnud üle 2,2 miljoni lehekülje (DGT Annual Activity Report 2017: 4). Euroopa Komisjoni kirjaliku tõlke peadirektoraadi eesti keele osakond tõlkis 2017. aastal eesti keelde üle 75000 lehekülje ja 2018. aastal ligi 86000 lehekülge eurotekste. Kõigi EL-i institutsioonide eesti keelde tõlgitavate eurotekstide maht on 200 000-250 000 lehekülge aastas. ${ }^{6}$ Seega, igal aastal lisandub Brüsselist ja Luxembourgist eestikeelse kultuuri hulka sadu tuhandeid lehekülgi õigustekste, nende väljatöötamise kavatsusi ja eelnõusid, poliitilisi, majanduslikke, rahanduse ja eelarve valdkonna, informatsioonilisi jms dokumente, pressitekste ning teisi avalikkusele mõeldud publikatsioone. Need tekstid on Eestis nähtavad. EL-i institutsioonide tõlketeenistused ja nendes töötavad inimesed on Eestile enamasti nähtamatud.

Eurotekste tõlgitakse eesti keelde kaheksas EL-i institutsioonis ja asutuses. ${ }^{7}$ Praktikas tähendab see seda, et eesti keelde tõlkijad töötavad üksteisest eraldi eri linnades oma institutsiooni sisemiste tõlkereeglite alusel. Sellisel tõlkekogukonna fragmenteeritusel on oma riskid, eriti tõlkijate koolitamisel ja kodumaaga sidemete arendamisel. Samuti võivad institutsiooniti erineda tõlkimise metoodika, kvaliteedikontroll, terminitöö ja tõlkimise organisatsiooniline ning tehniline protsess. EL-i ühtse tõlkekeskuse loomine on ideena olnud erialaringkondades päevakorras juba pikka aega, kuid 2018. aastal liikmesriikide poliitilist otsust tõlketöö selliseks tsentraliseerimiseks lähiajal ette näha ei ole.

Tööstuslik tõlkeprotsess erineb tavatõlkimisest. Selle staadiumid on originaali tehniline eeltöötlemine (ingl pre-processing; sh varasemate tõlkemäludega võrdlemine, masintõlke faili lisamine, tehniline töötlus vastavas tööformaadis), tõlkimine, toimetamine (jm kvaliteedikontrolli vormid), terminoloogiatöö, tõlke tehniline järeltöötlemine jms. See ühtne tööprotsess on reeglina jaotatud tõlkijate ja tõlkeassistentide vahel. Nõukogus ja komisjonis kuuluvad tõlkija tuumikülesannete (ingl core functions) hulka kolm omavahel üheks protsessiks seotud tegevust: tõlkimine, toimetamine (ingl revision) ja terminoloogiatöö. Lisaks pakutakse mitmeid teisi tõlkimisega seotud keele-

${ }^{6}$ Kasutatud on komisjoni tõlkepeadirektoraadi sisemist statistikat. Kõigis institutsioonides aasta jooksul eesti keelde tõlgitud täpset lehekülgede arvu pole hetkel võimalik anda, sest institutsioonid kasutavad mõnevõrra erinevaid statistikameetodeid.

${ }^{7}$ Nendeks on Euroopa Komisjoni kirjaliku tõlke peadirektoraat (DGT) Luxembourgis, EL-i Nõukogu tõlketeenistus (Translation Service) Brüsselis, Euroopa Parlamendi kirjaliku tõlke peadirektoraat (DG TRAD) Luxembourgis, Euroopa Liidu Kohtu mitmekeelsuse peadirektoraat Luxembourgis (kus töötavad vaid õigusharidusega keelejuristid), Regioonide Komitee ning Majandus- ja Sotsiaalkomitee ühendatud tõlketeenistus Brüsselis, Euroopa Kontrollikoja tõlketeenistus Luxembourgis, Euroopa Liidu Asutuste Tõlkekeskus Luxembourgis ja Euroopa Keskpanga tõlketeenistus Frankfurdis. Keelejuristid töötavad komisjoni, nõukogu ja parlamendi õigusteenistustes. Suulise tõlke eesti keele üksused on komisjonis, parlamendis ja kohtus. 
teenuseid: dokumendi toimetamine enne tõlkimist ehk originaali toimetamine (ingl editing); kirjalike ja suuliste kokkuvõtete tegemine sihtkeeles jms. EL-is on tõlkimine teenus, mis peab olema kättesaadav katkestusteta. Sageli tuleb ette dokumente, mille tõlkimise tähtajaks on antud paar tundi. See eeldab nn kiirreageerimistõlkimise süsteemi olemasolu.

Õigusaktide tõlkimisel lisanduvad tööprotsessi ka keelejuristid (ingl lawyer-linguists). Organisatsiooniliselt ei kuulu keelejuristid tõlketeenistuse, vaid reeglina õigusteenistuse koosseisu. Just Brüsselis töötavad nõukogu ja parlamendi keelejuristid on need, kes vastutavad kõigi Euroopa Liidu Teatajas avaldatavate õigusaktide ja EL-i rahvusvaheliste lepingute eestikeelse tõlke lõppteksti kvaliteedi eest. EL-i tõlkijate ja keelejuristide abistamiseks on välja töötatud mitmeid üldisi ja keelepõhiseid metoodilisi dokumente (vt Institutsioonidevaheline stiilijuhend 2011).

EL-i institutsioonides tõlgitakse erinevaid dokumenditüüpe: õigusakte (määrusi, direktiive, otsuseid; parlamendis ka eelnõude parandusettepanekuid jms), poliitilisi ja majandusdokumente, eelarve- jm rahandusdokumente, pressiteateid, veebitekste, institutsioonide protsessuaalseid dokumente (päevakorrad, protokollid, õigustalituste arvamused, kodanike arvamused jms), infomaterjale avalikkusele (mõned nendest on ilukirjanduslikus stiilis tekstid) jms. Tõlgitavate dokumenditüüpide arv ületab paari tosina piiri. Eesti keeles on saadaval kogu EL-i õigusnormistik (pr acquis communautaire), kogu jooksev päevakajaline teave EL-i kohta (pressiteated) ja informatsioon kõigi EL-i tegevusvaldkondade kohta. Üksikutel juhtudel on EL-i tõlkijal võimalus end teostada ka ilukirjanduse või luule alal, näiteks tõlkisid minu kolleegid nõukogus ühe avalikkusele mõeldud infoväljaande jaoks nõukogu endise presidendi Herman Van Rompuy haikusid. Samal ajal läbiti ka sellisel ilukirjanduse tõlkimisel kõik meie tööstusliku tootmise traditsioonilised staadiumid.

EL-i institutsioonide tööstuslik tõlkimine mõjutab ka Eesti tõlketurgu. Mitmed institutsioonid (sh komisjon, parlament, Euroopa Kohus, komiteed) tellivad arvestatavas koguses tõlketöid lepingu alusel väljastpoolt. Nende osakaal on institutsiooniti erinev, kuid jääb praegu $20-30 \%$ vahele. ${ }^{8}$ Suuremas osas teevad selle tõlketöö ära Eesti tõlketurul Eesti tõlkebürood ja üksikettevõtjad, kes on selleks valitud range EL-i avaliku hanke menetluse alusel. Ei ole haruldane, et sellise hanke võidab Poola, Kreeka või mõne teise riigi suur tõlkebüroo, kes allhanke korras tellib tõlked ikkagi Eestist. Teeme veel ühe järelduse: EL-i institutsioonid ja Eesti tõlketurg on majanduslike sidemete kaudu rohkem seotud, kui seda sageli osatakse arvata. Lähiaja perspektiivis on Eesti tõlketurult tellitavate dokumentide maht ligi kolmandik komisjoni ja parlamendi tõlkemahust.

${ }^{8}$ Euroopa Komisjoni eesti keele osakonnas on välistõlke maht aastatel 2017-2018 olnud suurusjärgus $28 \%$. Euroopa Liidu Nõukogu eesti keele osakond ei telli ühtegi tõlketööd väljast ja tõlgib kõik oma dokumendid ise. Vajadusel ja võimalusel abistavad EL-i institutsioonid üksteist ja tõlgivad ka teiste institutsioonide dokumente (nn interinstitutional workload balancing). 


\section{Keeletööstuse uurimine}

Akadeemik Karl Pajusalu väidab, et riik peab hoidma korras oma keelemajanduse. ${ }^{9}$ Ta rõhutab, et keelemajandus ilma seda koos hoidva kultuurita ei saa olla majanduslikult edukas (Pajusalu 2018). Ka minu arvates oleks vaja uurida Eesti keeletööstuse olukorda ja eraldi tõlketööstuse osa selles. Euroopa Komisjon on tellinud või osalenud mitmes keeletööstuse-alases uuringus ja omab vastavat metoodikat. Komisjoni DGT kodulehel on iseseisev keeletööstuse veebileht Language Industry Web Platform (LIND-Web). ${ }^{10}$ Samast leiab ka värskeima uuringu Euroopa keeletööstuse kohta (Language Industry Survey 2018).

On märgilise tähendusega, et 2018. aasta Wiedemanni konverentsi järel on nii Euroopa Komisjoni kirjaliku tõlke peadirektoraadi eesti keele osakonnal kui ka Tartu Ülikoolil ühine huvi Eesti keeletööstuse kaardistamise ja teadusliku uurimise vastu. Oluline roll sellise uurimuse läbiviimisel on haridus- ja teadusministeeriumil: viimase osavõtuta ei oleks selline uurimistöö esinduslik ega omaks praktilist väljundit.

\section{Euroopa õigust luuakse tõlkimise protsessis}

Tõlkimine on lahutamatu osa Euroopa Liidu õigusloomest. Tõlkijatel ja keelejuristidel on oluline roll Eesti õiguskeele loomisel ja arendamisel. Sellepärast vaadeldaksegi komisjonis tõlkimist otsustusprotsessi ühe osana (Translation as Part of the Commission's Decision-making Process).

Õigusaktide tõlkimisel on tõlkijal eriline vastutus. Tõlkides luuakse käitumisreegleid, mis on Eestis täitmiseks kohustuslikud (määrused, komisjonile delegeeritud õigusaktid ja rakendusaktid). Eesti seadusandja võtab direktiivid sageli üle eestikeelse tõlke sõnastuses.

EL-i õiguse ja õiguskeele loomine on küllaltki keerukas protsess, millega eri etappides on seotud komisjon, nõukogu ja parlament, nii tõlkijad kui ka keelejuristid. Luule tõlkimist on võrreldud viiulisonaadi esitamisega tromboonil. Õigusakti tõlkimist võib aga võrrelda selle akti ise kirjutamisega. Üks EL-i õigusloome risk on, et selles osaleb palju õigushariduseta inimesi, kes loovad spetsiifilisi õigustekste nii originaalis kui ka neid tõlkides. Ka eesti tõlkekogukond koosneb peamiselt (võõr)filoloogidest, oluliselt väiksem on muude humanitaar-, sotsiaal- ja reaalteaduste taustaga tõlkijate arv. Õigusharidusega tõlkijad töötavad Euroopa Liidu Kohtu tõlketeenistuses ja ka nõukogu ning parlamendi keelejuristidena, tõlkeosakondades on neid mõni üksik.

Üldlevinud on müüt, et tõlkija vastutab kõige eest, mis Brüsselist ja Luxembourgist tuleb. Ei, kõigi EL-i õigusaktide puhul, mis läbivad komisjonis, nõukogus ja parlamendis seadusandliku protsessi, on keelejuristidel viimase sõna õigus EL-i õigusakti ja rahvusvahelise lepingu terminoloogia ja sõnas-

9 Pajusalu soovitab eesti keeles kasutada terminit keelemajandus. Mina tuginen komisjonis kasutatavale terminoloogiale ja olen selles artiklis sünonüümina tarvitanud terminit keeletööstus.

${ }^{10} \mathrm{https}$ ://ec.europa.eu/info/departments/translation/language-industry-facts-andfigures-lind-web_en 
tuse osas. Seega on Euroopa Liidu Teatajas avaldatud eestikeelne õigusakt tõlkijate mõttetöö tulemus, kuid selle lõppvariandi osas jagatakse vastutust keelejuristidega.

Kui palju seda Euroopa õigust üldse on, mis Eesti õigussüsteemi ja õiguskultuuri mõjutab? Allpool on antud mõned suhtarvud suurusjärgust ülevaate saamiseks.

Enne Eesti ühinemist Euroopa Liiduga 2004. aastal tõlgiti Eesti Õigustõlke Keskuses 91674 lehekülge EL-i õigustekste. Horvaatia ühinemisel 2013. aastal oli EL-i õigustiku ja järelikult ka tõlgitavate õigustekstide maht kasvanud 154000 leheküljeni (Pisuke 2015: 4). Praegu ületab liikmesriike siduvate erineval tasemel õigusdokumentide maht 200000 lehekülje piiri. Osa EL-i õigusakte (määrused) on Eestile vahetult siduvad selles eestikeelses sõnastuses, mis neile Luxembourgis ja Brüsselis antakse. Direktiivid ühtlustatakse liikmesriikides, kasutades selleks reeglina institutsioonide tõlgetes antud mõisteaparaati ja sageli ka täpset sõnastust. EL-i õigusaktide hulka kuuluvad ka otsused, millest paljud tõlgitakse eesti keelde. Mitut liiki komisjoni õigusaktid (delegeeritud aktid ja rakendusaktid) on Eestis samuti otsekohaldatavad komisjoni tehtud tõlke sõnastuses.

Viimase viie ja poole aasta jooksul (2013 kuni 2018. aasta aprill) on EL-is vastu võetud 171 parlamendi ja nõukogu määrust ning muudetud 147 määrust. Vastu on võetud 71 parlamendi ja nõukogu direktiivi ja muudetud 45 direktiivi. Komisjoni otsekohalduvate aktide hulk on järgmine: 285 uut delegeeritud määrust ja 212 määruse muutmist, üks uus ja kolm muudetud komisjoni direktiivi. Komisjonis on selle perioodi jooksul vastu võetud 1802 ja muudetud 1057 rakendusmäärust, kaheksa uut rakendusdirektiivi ja 19 rakendusdirektiivi muutmist. Need arvud illustreerivad nii õigusloome üldist suhtarvu kui ka eesti keelde tõlgitavate õigusaktide hulka. ${ }^{11}$

\section{Tõlkimine ja terminoloogiatöö}

Terminoloogiatöö on komisjoni ja nõukogu, samuti parlamendi ja kohtu tõlkeprotsessi lahutamatu osa. Lõppväljundiks on uus kanne või varasema kande täpsustamine või kustutamine Euroopa interaktiivses terminibaasis IATE (Interactive Terminology for Europe). Tegelikult on olemas kolm IATE andmebaasi, millest kaks on kõigile huvilistele avatud (nn IATE Public ja Download IATE). ${ }^{12}$

Miks mitte kasutada Eesti õigusaktide termineid? Seda ka tehakse, kuid see on võimalik vaid teatud ulatuses. EL-i institutsioonides tehtaval terminoloogiatööl on oma spetsiifika ja metoodika. On valdkondi, mis pole Eesti õigusega reguleeritud ja kus vastav eestikeelne terminoloogia tuleb alles luua.

11 Kogusin need andmed EL-i seadusandluse ametlikus andmebaasis EUR-Lex avaldatud statistikast, vt https://eur-lex.europa.eu/statistics/legislative-acts-statistics.html

${ }^{12}$ Institutsioonidevaheline ühtne terminibaas IATE loodi 2005. aastal. Enne seda oli igal institutsioonil oma andmebaas. IATE-s on termineid rohkem kui 120 keeles. Terminite maht ja valik on esinduslik ainult EL-i ametlikes keeltes. Kõik eri institutsioonide terminoloogide ja tõlkijate IATE-sse sisestatavad terminid on kolme minuti pärast kogu kasutajaskonnale nähtavad. 2018. aasta lõpus käivitus edasiarendatud IATE 2. IATE on autoriõigusega kaitstav andmebaas. 
Ka kattuvates valdkondades peetakse silmas Euroopa Liidu Kohtu lahendites antud tõlgendusi ja soovitusi. Näiteks on kohus väitnud, et EL-i õigusaktides kasutatakse vaid Euroopa õigusele omast terminoloogiat, seega liikmesriigi õiguses kasutatavaid mõisteid ja terminoloogiat tuleks vältida (vt Pisuke 2015: 2). Vaid nii on võimalik saavutada terminoloogiline ühtsus kõigis EL-i ametlikes keeltes.

Esitan mõne näite. Koostöös Eesti ekspertidega loodi nõukogus hulgaliselt uusi termineid Iraaniga sõlmitud tuumakokkuleppe dokumentide tõlkimisel eesti keelde. IATE-sse on sisestatud eetikeelsed EL-i dokumentides esinevad kala-, linnu- ja taimenimed. Eesti Looduseuurijate Seltsi botaanika terminoloogia komisjoni ning Euroopa Komisjoni tõlkijate ja terminoloogide koostöös leiti eesti keeles suur hulk sobivad vasteid (näiteks Archidendron pauciflorum - haisev koerakaunapuu; Citrus natsudaidai - jaapani mõru apelsinipuu; Solanum torvum - hernesbaklažaan jne). ${ }^{13}$

IATE andmebaas sisaldab termineid kõigi Euroopa Liidu tegevusvaldkondade kohta. 2018. aasta 30. septembri seisuga oli IATE-s 60249 eestikeelset terminit. Ühel terminikaardil võib olla ka mitu terminit. Komisjoni eesti keele osakonnas loodi 2018. aastal koostöös Eesti ekspertidega ligi 1900 uut terminit. Kui lisada siia nõukogus ja parlamendis loodud terminid, siis näitab 2018. aasta statistika IATE andmebaasi stabiilset kasvu 2500-3000 uue termini võrra aastas.

Eestikeelsete terminite arvu IATE andmebaasis aastate lõikes näitab tabel 1. IATE statistika avaldatakse Eestis esmakordselt. ${ }^{14}$

Institutsioonide terminoloogiatöö toimub tihedas koostöös Eesti Keele Instituudi (EKI), mitmete terminoloogiakomisjonide ja Eesti ekspertidega. Ilma Eesti ekspertide osavõtuta ei looda ühtegi uut terminit ega muudeta vana. See on institutsioonide eesti keelekogukonna tava (mitte õiguslik kohustus). Euroopa õigus ei kohusta kasutama EL-i õigusaktide tõlgetes rahvuslikes õigusaktides kasutatavat terminoloogiat. Sellepärast on eriti tähtis, et EL-i institutsioonide ja Eesti ministeeriumide, ülikoolide ja ekspertide koostöö toimiks ladusalt.

EL-i institutsioonidel on terminoloogiatöös väga konkreetsed huvid koostööks Eestiga: 1) saada võimalikult kiiresti asjakohane ja ekspertide omavahel kooskõlastatud vastus oma küsimustele (märksõnad: kiirus, kooskõlastamine, kvaliteet); 2) jõuda võimalikult kiiresti ja ilma vaheetappideta õige eksperdini (vajalik on võrgustik ja ühtne kontaktpunkt); 3) ühendada sisuline erialaekspertiis eesti keele ekspertiisiga (EKI oluline roll tagasiside protsessis).

Eestis loodav terminoloogiavõrgustik saab viia kogu siinse koostöö suure sammu võrra edasi. Haridus- ja teadusministeeriumile ja Eesti avalikkusele on edastatud EL-i institutsioonide seisukohad ja ettepanekud terminoloogiavõrgustiku võimaliku ülesehituse kohta (Pisuke 2017: 4-6).

EL-i institutsioonide terminoloogiatöö annab olulise panuse eesti oskuskeele arendamisse. Selliseks väiteks annab aluse nii IATE statistika kui ka nende valdkondade, mille raames institutsioonide terminoloogid ja tõlkijad eesti keele oskussõnavara arendamisse panustavad, keerukus.

${ }^{13}$ Vt ka http://taimenimed.ut.ee.

${ }^{14}$ Info pärineb Euroopa Liidu Asutuste Tõlkekeskusest Luxembourgis, mis on IATE andmebaasi ametlik haldaja. 


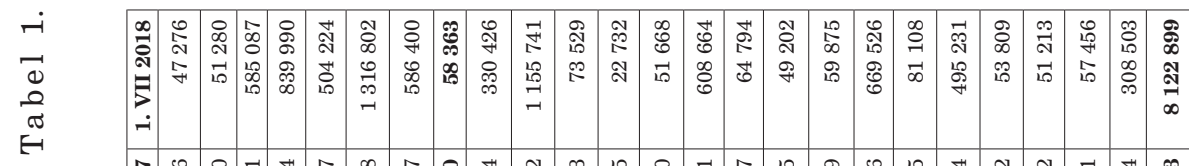

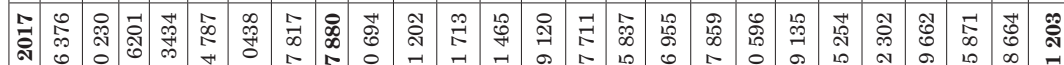
震

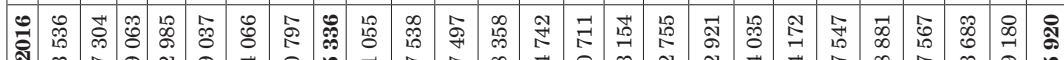

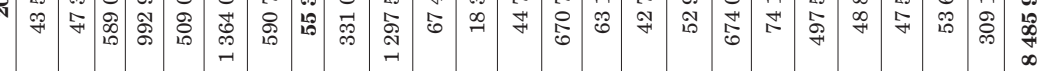

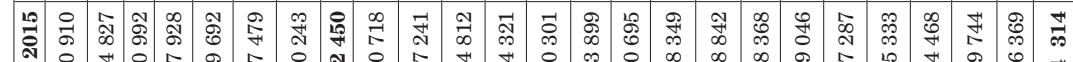

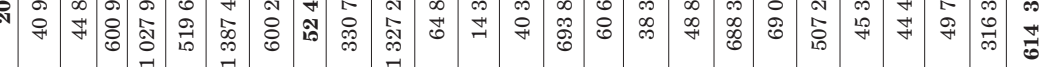

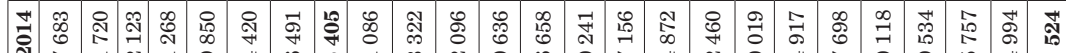

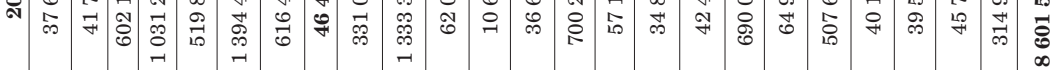

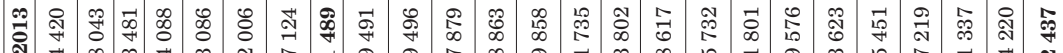

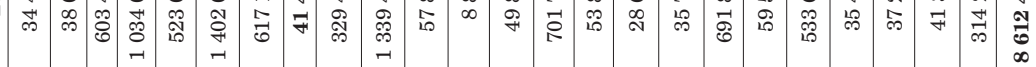

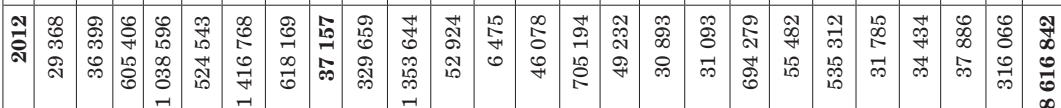

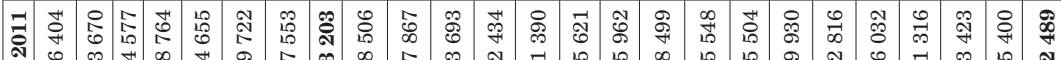
舟

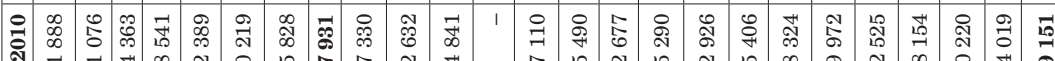

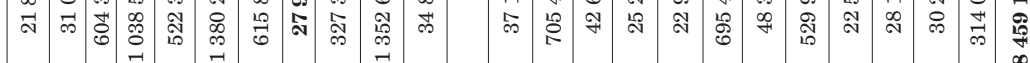

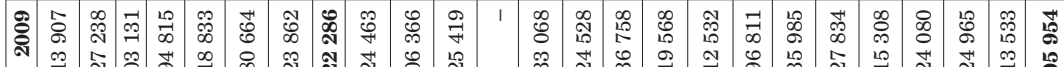
ఇ ล

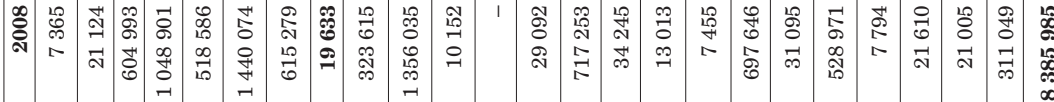

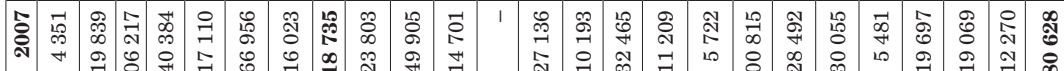

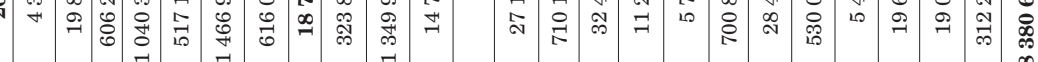

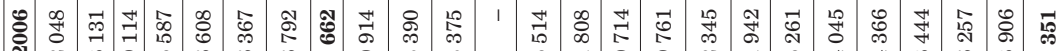

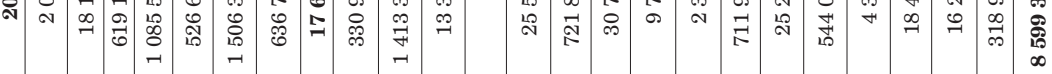

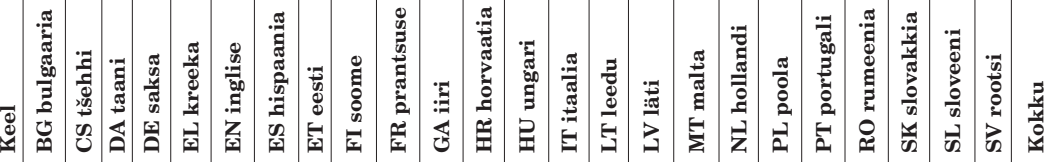




\section{Muutused tõlkija elukutses ja staatuses}

Tööstusliku tõlke tingimustes erineb tõlkija töö oma n-ö romantilise ametivenna tööst. Kuigi ka viimane ei saa läbi tänapäevaste tehniliste abivahenditeta, on ta tõlkevalikutes oluliselt vabam. Institutsioonide tõlkemetoodika nõuab võimalikult täpset teksti mõtte ja sõnastuse edasiandmist. See võib tunduda sisuliselt kohmakas ja mitte täielikus vastavuses keelereeglitega, kuid kui lähteteksti sõnastus nõuab, tuleb see ka eesti keeles täpselt edasi anda. Õigusaktide eelnõud ja poliitilised avaldused luuakse sageli liikmesriikide tuliste vaidluste tingimustes ja kompromisside teel. Sageli on üheselt mittearusaadavus ja teatud tõlgendamise võimalus sisse kirjutatud originaali teksti. Tõlkija peab olema võimeline sellise eelnõu või dokumendi vahendama eesti keelde ilma omapoolsete loominguliste ilustusteta.

Tehniliselt keeruline tõlkeprotsess on sisenemas uude arenguetappi. Arvutipõhiste töövahendite (ingl computer assisted translation (CAT) tools) hulka kuuluvad EL-i institutsioonides SDL Trados Studio, tõlkemälud (Euramis jms), andmebaasid (EUR-Lex, Eurovoc jms), metaotsingusüsteemid (Quest metasearch), masintõlge jms.

2018. aasta juunis mindi komisjonis statistiliselt masintõlkelt MT@EC üle neuromasintõlkele eTranslation. ${ }^{15}$ Lähiajal saab kasutada paralleelselt mõlemat süsteemi. Komisjonis arendatud masintõlget kasutavad ka teised EL-i institutsioonid. Võimalus komisjoni neuromasintõlke kasutamiseks on ka liikmesriikide riigiasutustel ja European Master in Translation (EMT) võrgustikku kuuluvatel ülikoolidel. Statistika näitab, et võrreldes mõnede teiste liikmesriikidega ei kasutata Eesti riigiasutustes komisjoni masintõlget just väga aktiivselt. EMT võrgustikku ükski Eesti ülikool 2018. aasta seisuga ei kuulu.

Mis puutub praegusesse komisjoni eestikeelse masintõlke praktilisse rakendatavusse ja tõlkekvaliteeti, siis on see veel dünaamilises arenguprotsessis (vt Sibul 2018: 7). Tulemused on paranenud iga aastaga. Mõne teise keelepaari (näiteks inglise-hispaania, inglise-prantsuse, inglise-portugali jms) tõlke kvaliteet on juba praegu teatud dokumenditüüpide puhul väga hea. Eesti, soome, ungari ja saksa keele tõlkemootoritega tegeletakse aga eraldi, arvestades nende keelte eripära. Võimalikult rohke kasutamine ja kasutajate tagasiside annab komisjonile võimaluse eestikeelset tõlkemootorit arendada. Tuleb arvestada, et Euroopa Komisjoni masintõlke arendamine on suunatud esmajoones EL-is loodavate dokumenditüüpide tõlkimisele ja seda arendatakse tõlketööstuse rakenduslikel eesmärkidel. See ei ole mõeldud armastuskirjade ega luule tõlkimiseks, see ei võistle näiteks TILDE ${ }^{16}$ ega Tartu Ülikooli ${ }^{17}$ masintõlkemootoritega igapäevatekstide tõlkimisel.

Kas masin hakkab tõlkima eesti keelde ka õigusakte? Tuleviku perspektiivis kindlasti, kuid mitte ilma inimese abita. Tuleb silmas pidada, et on erinevat liiki õigusdokumente. Mõnda nendest saab masinale usaldada, mõnda aga ka tulevikus nähtavasti mitte.

${ }^{15}$ Euroopa Komisjoni masintõlkesüsteemid on kättesaadavad järgmistel aadressidel: eTranslation https://webgate.ec.europa.eu/etranslation ja MT@EC https://https://mtatec. ec.testa.eu/mtatec

${ }^{16} \mathrm{http}: / / \mathrm{www} \cdot$ tilde.ee/masintolge

${ }^{17} \mathrm{http} / / /$ neurotolge.ee/ 
2018. aasta tõlketuru uuringust selgus, et masintõlge on Euroopa tõlketööstuse üks päevakajalisemaid ja eriarvamusi tekitavamaid küsimusi (Language Industry Survey 2018: 29-30).

Tõlkemasin ei võta tõlkijalt tööd. Aga tõlkija töö, profiil ja staatus muutuvad. Tõlkija tööl on rohkem tehnilisi funktsioone, see sisaldab toimetamist, projektijuhtimist ja kommunikatsiooni. Euroopa Parlamendis on kaalutud isegi tõlkija ametinimetuse muutmist, et selles väljenduks kultuuride vahendaja roll ja et see hõlmaks kõiki tõlkija tegevusvaldkondi, sh tõlkimist, toimetamist, kohandamist, terminoloogiatööd, keelenõu andmist jms. Uue aja tõlkija tegevust väljendavaks terminiks on inglise keeles pakutud intercultural linguistic mediation. Kõiki neid arenguid tuleks Eesti ülikoolides arvestada tõlkijate ettevalmistamisel. Nende hulgas õpetatakse ka tulevasi eurotekstide tõlkijaid.

European Master in Translation on praegune Euroopa tõlkeõpetuse standardeid seadev võrgustik ja tõlkeõpetuse kvaliteedimärk. Uues tõlkija kompetentside raamistikus tuuakse välja viis nüüdisaja tõlketuru nõuetele vastavat tõlkija kompetentsivaldkonda ja 35 vajalikku oskust (EMT competence framework: 3-11).

\section{Kas sellist eurokeelt me siis tahtsimegi ehk eurokeele müüdid ja tegelikkus}

2018. aasta Wiedemanni konverentsil märkisid mitmed esinejad, et nn eurokeel on silmale kole vaadata ja kõrvale valus kuulata. Arvan, et näiteid sellise väite illustreerimiseks leidub küll. Aga vaatleme asja laiemas kontekstis. Lööge lahti suvaline Eesti õigusakt ja analüüsige õigusnorme sama silmailu ja kõrvapaitamise kriteeriumi alusel. Ja pole vist üllatus, kui me enda eestimaisest ja EL-iga üldse mitte seotud õigusloomingust leiame täpselt samadele tunnustele vastavaid näiteid - ja mitte vähe. Siin tuleb püstitada küsimus, kas nn õiguskeelele kui oskuskeele ühele osale tuleks läheneda üldse teiste kriteeriumide alusel? Väidan, et tuleb, sest õigusloome Euroopa Liidus ja ka Eestis erineb oluliselt tavaliste kirjalike tekstide loomisest.

Vaatleme asja lühidalt EL-i õiguse seisukohalt. Rahvusvaheline õigusakt, nii rahvusvahelise organisatsiooni konventsioon kui ka EL-i määrus või direktiiv, kujuneb samm-sammult erinevate etappide läbimisel. Eestikeelse lõppteksti analüüsimisel tuleb teha vahet kahe väga selgelt erineva dokumendi vahel: 1) õigusakti originaaltekst ja 2) selle tõlge. Originaaltekst kannab oma väljatöötamise esimeses etapis alati mingit kindlat poliitilist, majanduslikku või sotsiaalset ideed ja on struktureeritud väljatöötaja loogika alusel. See, reeglina Euroopa Komisjoni väljatöötatud terviktekst, satub järgnevalt erialaekspertide ja lobirühmade mõjutussfääri ning järgnevatel etappidel liikmesriikide ametlike ekspertide (Euroopa Liidu Nõukogus) ja poliitikute (Euroopa Parlamendis) kätte. Igaühel on oma erialased, isiklikud, grupi- või riiklikud huvid ja eelistused. Ei ole raske aru saada, et algsest, reeglina ühtsele loogikale ja terminoloogiale tuginevast õigusaktist jäävad pärast nõukogus ja parlamendis vastuvõtmist tihti järele vaid riismed. On üldse XX sajandi üks suurimaid sotsiaalseid arenguid, et 28 liikmesriiki oma erinevate traditsioo- 
nide, kultuuride ja huvidega on loonud sellise töötava süsteemi, mis viib ühtse tulemuseni. Jah, kui imperaator või monarh andis välja õigusakte, siis oli see ühe inimese või väikese grupi tahe. Tänapäeva Euroopa Liidu õigusaktid väljendavad vähemalt õigusteooria tasandil 28 liikmesriigi rahvaste tahet. Ja tahame seda või mitte, õigusaktide originaaltekstid on just niisama segased, nagu me neid eesti keeles loeme.

Analüüsi tulemusel jõuame järelduseni, et kriitika käib EL-i õigusakti kui sellise, ja mitte selle tõlke kohta. Tõlge vastab enamikul juhtudel täpselt originaali mõttele ja sõnastusele. Miks siis halvustada õigusakti eesti keelt ja naeruvääristada tõlkijat, kelle pihta selline kriitika - ükskõik kas otseselt või peidetud pilkega - kõige esimesena lendab?

Vaadakem peeglisse. Mitte ükski Euroopa Liidu õigusakt ei ole vastu võetud ilma Eesti riigi esindajate osavõtuta nõukogu töögruppides. Kõigi õigusaktide vastuvõtmisele on andnud lõpliku ametliku heakskiidu Eesti valitsus vastava ala ministri eelneval soovitusel. Eestist valitud poliitikud on olnud akti valmimise või vastuvõtmise juures Euroopa Parlamendis. Seega on igal EL-i õigusaktil Eesti riigiaparaadi heakskiitev või nõustuv pitser. Eesti ministeeriumidest, nende professionaalsetest ekspertidest ja juhtkonnast sõltub olulisel määral see, kuidas õigusakt hakkab eesti keeles välja nägema ja kõlama ning kas avalikkus saab õigeaegselt teada uue õigusakti filosoofiast ja terminikasutusest. Üldine riigihalduse praktika paljudes maades on näidanud, et mitte alati ei ole riigiaparaat valmis EL-i debattides professionaalselt osalema ja oma maa avalikkusega infot jagama. Ministeeriumide eesti keele alase professionaalsuse tõstmine on üks tee nii õigusaktide originaalide kui ka nende tõlgete kvaliteedi parandamisel.

Kas tõlkimine on täiesti iseseisev või on see keeleteaduse, semiootika või hoopis rakenduslingvistika osa? Kõigile neile küsimustele võib erialakirjanduses leida jaatavaid vastuseid. Brüsselist ja Luxembourgist vaadatuna on teooriast olulisem leida vastus praktilise koostöö küsimustele. Millisele Eesti telefoninumbrile helistades saab kiire ja kvaliteetse vastuse eesti keelt puudutavates küsimustes? Kellega Eestis üldse rääkida tööstusliku või rakendusliku tõlkimise või eurokeele teemadel?

Teooria tasandil saaksid institutsioonid panustada eurokeele (eurolekti) määratlemisse, mis peaks olema iseseisev süsteemne uurimisobjekt (Pisuke 2016: 9). Institutsioonidel on oma rakenduslik lähenemine siht- ja lähtekeelele (ingl target language ja source language) ja vastavatele tekstidele, millega oleks võimalik panustada näiteks tüviteksti uurimisse (Merilai 2017: 737). Eesti keele seisundi uurimise üheks kriteeriumiks võiks olla ka eesti keelde ja eesti keelest tõlkimine, mis praeguses keeleseisundi uuringus ei kajastu (Eesti keeleseisund 2017: 3-4). On õigustatult märgitud, et eesti kultuur on tõlkekultuur ning tõlkimine on seotud eesti keele arendamisega (Kaldjärv 2017: 939).

Seni on EL-i institutsioonide põhiliseks koostööpartneriks olnud Eesti Keele Instituut ja selle eurokeelehooldajad. ${ }^{18}$ EKI-ga on toimunud üle kümne aasta hea koostöö terminoloogia ja tõlkijate koolituse alal Brüsselis ja Luxembourgis. EL-i institutsioonid näevad Eesti Keele Instituudi juhtivat rolli ka võimalikus tulevases terminoloogiavõrgustikus.

${ }^{18} \mathrm{Vt}$ http://eurokeelehoole.eki.ee 


\section{Kokkuvõte}

Tõlkimine pole üksnes praktiline tegevus ja elukutse, vaid see on ka filosoofia ja elustiil. Tõlkimine on üksiku professionaali tegevusest muutunud dünaamiliseks tööstusharuks. Tõlgete masstootmine on muutnud inimeste- ja kultuuridevahelist kommunikatsiooni. Lisaks professionaalidele tõlgivad kõik, sealhulgas taksojuhid, kelnerid ja tarbijad. XXI sajandi tehnoloogiliste arengute ja globaalsete kommunikatsioonivahendite ja -võrkude tingimustes muutub tõlkimise filosoofia, teooria ja praktika. Need arengud on hästi jälgitavad ka Euroopa Liidu institutsioonide tööstuslikus tõlkeprotsessis ja tõlkija muutuvas elukutses. See ei jäta puutumata ka eesti keelt. Eesti keel on praegu palju globaalsem ja väljastpoolt tulevatele mõjutustele avatum, kui ta on olnud kunagi varem. Põhiline mõjutaja praegu ja lähiajal on Euroopa Liit seoses õiguste ja kohustustega, mis tulenevad liidu mitmekeelsuspoliitikast. Igal aastal lisandub eesti kultuurile üle 200000 lehekülje EL-i institutsioonides tõlgitud eurotekste ja tuhandeid uusi või kohendatud termineid.

Kas EL-i mõju kujutab meie keelele ohtu? Mina seda ei näe. Ohtu võib oodata pigem keelelises protektsionismis ja kapseldumises oma traditsioonilisele territooriumile. Me saame praegu kasutada neid otseseid ja kaudseid võimalusi, mida eesti keele arendamisele ja levitamisele pakub Euroopa Liit. Eesmärgiks ei ole eesti keele globaliseerimine, aga see protsess toimub omasoodu. Meil on võimalik kasutada meie ajaloo suurimat turgu oma keele kommertsialiseerimiseks ja kultuuri levitamiseks. Eesti keele sellise globaliseerimise põhiline meetod on tõlkimine.

Minu arvates on tõlkimine ja sellega seotud terminoloogiatöö meie senises eesti keele alases tegevuses olnud alahinnatud. Tõlkijad on sageli teenimatult sattunud esimesena kriitika alla kui koleda eurokeele autorid. Kuid ärgem unustagem, et tõlkija ei saa kanda vastutust originaali kvaliteedi eest. Euroopa Liidu ametlikku dokumenti ei tohi tõlkida ilusamaks, kui see on. Eurodokumendi tõlkimine toimub mitme EL-i institutsiooni ning tõlkijate ja keelejuristide (juristide-lingvistide) koostöös. Kõigi õigusaktide tõlkeprotsessis kuulub viimase sõna õigus keelejuristidele.

Tõlkimine on ja jääb ülitähtsaks tegevuseks ka siis, kui inimest abistavad või kohati asendavad tõlkivad masinad. Selliseid arenguid tuleb ette näha ja nendeks valmis olla. Eesti ülikoole ootavad suured väljakutsed: valmistada ette uue põlvkonna tõlkijaid ja saada Euroopa Komisjoni hallatava võrgustiku European Master in Translation liikmeks.

Tõlkimine on Eesti jaoks riikliku tähtsusega äriidee. Tõlkijate tõstmine poodiumile koos teiste eesti keele arendajatega mõjub hästi nii eesti keelele kui ka selle mainekujundusele. Tõlkimine, nii traditsiooniline ajaloolis-romantiline kui ka tööstuslik, ja sellega seotud terminoloogiatöö võiksid olla eraldi alaosaga tähtsustatud väljatöötatavas uues eesti keele arengukavas (Arengukava 2018).

Haridus- ja teadusminister Mailis Reps tänas Wiedemanni juubelikonverentsi avades „kõiki, kes eesti keele heaks töötavad”. Tänusõnadele järgnenud eesti keelde panustajate loetelus tõlkijaid, sh EL-i institutsioonide tõlkijaid, ei mainitud. Sajad tuhanded leheküljed Brüsselis, Luxembourgis ja Frankfurdis tõlgitud tekste ja tuhanded uued terminid on Eestis nähtavad. Nähtamatud on aga veel need inimesed, kes seda tähelepanuväärset tõlketööd teevad. 
2018. aasta nimetas Euroopa Komisjon kultuuripärandi aastaks. 2019. aastat tähistatakse ÜRO Peaassamblee ettepanekul kui rahvusvahelist põliskeelte aastat ja Eestis kui eesti keele aastat. Eesti keel on maailma kultuuripärandi osa. Tõlkimine kui spetsiifiline inimtegevus keelte ja kultuuride vahendamisel loob uut ühiskondlikku väärtust ja kultuuripärandit nii Eesti kui ka kogu maailma jaoks. Tänu tõlkijale!

Kõik artiklis avaldatud arvamused ja ettepanekud kuuluvad autorile ega esinda Euroopa Komisjoni ametlikke seisukohti.

\section{Kirjandus}

Arengukava 2018 = Eesti keelevaldkonna arengukava 2018-2027. Keel loob väärtust. (Eelnõu.) Haridus- ja Teadusministeerium, märts 2018. https://www. hm.ee/sites/default/files/eesti_keelevaldkonna_arengukava_eelnou_8.03.2018. $\operatorname{pdf}(31$. XII 2018).

DGT Annual Activity Report 2016 = Annual Activity Report. Directorate-General for Translation, European Commission. https://ec.europa.eu/info/sites/info/files/ file_import/aar-dgt-2016_en_0.pdf (31. XII 2018).

DGT Annual Activity Report 2017 = Annual Activity Report. Directorate-General for Translation, European Commission. https://ec.europa.eu/info/sites/info/files/ file_import/dgt_aar_2017_final.pdf (31. XII 2018).

Dreving, Marek 2014. Pidurdamatult kasvav infohulk nõuab tõlkimiselt uutmoodi käsitlusviisi. - Õiguskeel, nr 3. https://www.just.ee/sites/www.just.ee/ files/marek_dreving._pidurdamatult_kasvav_infohulk_nouab_tolkimiselt_uutmoodi_kasitusviisi.pdf (31. XII 2018).

Eesti keeleseisund 2017 = Eesti keeleseisund. Aruanne mai 2017. TÜ sotsiaalteaduslike rakendusuuringute keskus, Balti Uuringute Instituut. https://www. ibs.ee/wp-content/uploads/aruanne_2017.pdf (31. XII 2018).

EMT Competence Framework = European Master's in Translation Competence Framework 2017. https://ec.europa.eu/info/sites/info/files/emt_competence_ fwk_2017_en_web.pdf (31. XII 2018).

IATE = InterActive Terminology for Europe. http://iate.europa.eu/SearchByQueryLoad.do;jsessionid=86Vre5e3faVbNr9BC0Y5kwqVDzlRs7SacuZIfeMbtbnpczize BL7!-2090179866?method=load (31. XII 2018).

Ilj a, Merit 2011. Eurotekstide tõlkimise põhimõtetest ja probleemidest. - Õiguskeel, nr 1. https://www.just.ee/sites/www.just.ee/files/merit_ilja._eurotekstide_ tolkimise_pohimotetest_ja_probleemidest.pdf (31. XII 2018).

Institutsioonidevaheline stiilijuhend. Brüssel-Luxembourg: Euroopa Liidu Väljaannete Talitus, 2011. http://publications.europa.eu/code/et/et-000100.htm (31. XII 2018).

Kaldjärv, Klaarika 2017. Teooria ja praktika vahel ehk ikka puuduvast tõlkekriitikast. - Keel ja Kirjandus, nr 12, lk 939-943.

Language Industry Survey $2018=$ Expectations and concerns of the European Language Industry 2018. https://ec.europa.eu/info/sites/info/files/2017_language_industry_survey_report_en.pdf (31. XII 2018).

Merilai, Arne 2017. Tüviteksti mõistest. - Keel ja Kirjandus, nr 10, lk 737-752. 
Nõukogu 15. aprilli 1958. a. määrus nr 1, millega määratakse kindlaks Euroopa Majandusühenduses kasutatavad keeled. - Euroopa Ühenduste Teataja (EÜT) 17, 6.10.1958, Euroopa Liidu Teataja (ELT) eriväljaanne 01/01, lk 3.

Paju s alu, Karl 2018. Uuenev eesti keel: mida on õppida saja aasta kogemusest. - Ettekanne Ferdinand Johann Wiedemannile pühendatud rahvusvahelisel konverentsil „Emakeelne Eesti, emakeelne Euroopa III” 24. IV 2018 Rakveres.

Pi s u ke, Heiki 2013. Eurokeelest, eurotekstide tõlkimisest ja tõlkijatest. - Riigikogu Toimetised, nr 27, lk 9-20. https://rito.riigikogu.ee/eelmised-numbrid/ nr-27/eurokeelest-eurotekstide-tolkimisest-ja-tolkijatest/ (31. XII 2018).

Pisuke, Heiki 2015. Õigusaktide tõlkimine Euroopa Liidu institutsioonides. Õiguskeel, nr 2. https://www.just.ee/sites/www.just.ee/files/heiki_pisuke._oigusaktide_tolkimine_euroopa_liidu_institutsioonides.pdf (31. XII 2018).

Pis u ke, Heiki 2016. Kus on eurokeele kodu? - Õiguskeel, nr 1. https://www.just. ee/sites/www.just.ee/files/heiki_pisuke._kus_on_eurokeele_kodu.pdf (31. XII 2018).

Pis uke, Heiki 2017. Tõlkimine ja uus eesti keelestrateegia. - Õiguskeel, nr 3. https://www.just.ee/sites/www.just.ee/files/heiki_pisuke._tolkimine_ja_uus_ eesti_keelestrateegia.pdf (31. XII 2018).

Rahvahääletuse tulemuste kinnitamine. Vabariigi Valimiskomisjoni 05.10.2003 otsus. Vastu võetud 03.10.2003 nr 90. RT I 2003, 63, 426. https://www.riigiteataja.ee/akt/630398 (31. XII 2018).

Sibu l, Ingrid 2018. Masintõlge ja eestikeelsed õigustekstid - ühe tõlkija senised kogemused Euroopa Komisjonis. - Õiguskeel, nr 2. https://www.just.ee/sites/ www.just.ee/files/ingrid_sibul._masintolge_ja_eestikeelsed_oigustekstid_-_ uhe_tolkija_senised_kogemused_euroopa_komisjonis.pdf (31. XII 2018).

Teras, Liina 2017. Õigustõlke võlud ja valud Euroopa Liidu kohtusüsteemis. Kohtute aastaraamat 2017, lk 83-93. http://www.ekou.ee/mat/Kohtute-aastaraamat-2017.pdf (31. XII 2018).

Translation as Part of the Commission's Decision-making Process. Communication to the Commission. Brussels, 22.4.2016 C(2016) 2000 final. http://ec.europa.eu/ transparency/regdoc/rep/3/2016/EN/3-2016-2000-EN-F1-1.PDF (31. XII 2018).

Uus mitmekeelsuse raamstrateegia $=$ Uus mitmekeelsuse raamstrateegia. Euroopa Komisjoni teatis Nõukogule, Parlamendile, Euroopa Majandus- ja Sotsiaalkomiteele ning Regioonide Komiteele. Brüssel 22.11.2005, KOM(2005) 596 lõplik. https://www.hm.ee/sites/default/files/mitmekeelsuse_raamstrateegia.pdf (31. XII 2018).

Heiki Pisuke (snd 1955), PhD, Euroopa Komisjoni kirjaliku tõlke peadirektoraadi eesti keele osakonna juhataja (European Commission DGT, ARIA 00 / B040, L-2920, Luxembourg); Tartu Ülikooli külalisprofessor, heiki.pisuke@ec.europa.eu

\section{About translation in the EU institutions}

Keywords: translation, translators, translation studies, legislation, translation industry, machine translation

This article examines mainly four topics: 1) the impact of the European Union's multilingualism policy on the Estonian language, 2) the role of translation in 
implementing multilingualism, 3) the translation pipeline in EU institutions, and 4) changes in the translator's profession. Based on statistics, the author shows that the Estonian language entities in eight EU institutions translate yearly more than 200,000 pages of EU documents into Estonian. At the same time terminologists and translators of the Commission, Council and European Parliament introduce several thousand new terms into the IATE database (InterActive Terminology for Europe). The total number of Estonian terms in IATE covering all fields of the activity of the EU is 60,249 (by 30.09.2018). The author argues that the multilingualism policy and the status of being one of the 24 official languages creates favourable conditions for the development of the Estonian language. At the same time, the author highlights some problematic areas and risks which may affect the Estonian culture due to the so-called Eurolanguage, a by-product of EU legislation drafting and translations.

The author also looks into the role of translation in the EU legislative procedure, issues related to machine translation and changes in the translator's profession, based on the new European Master in Translation (EMT) Competence Framework. The author makes some proposals to enhance cooperation between the translation departments of EU institutions and Estonian authorities, as well as suggests some joint research topics (e.g. translation industry, Eurolanguage/ Eurolect, etc.). The main idea underlying the article is that the current industry based translation process and methodology used in the EU institutions differs from the traditional romantic concept of authorship used for centuries in translation theory and practice.

Heiki Pisuke (b. 1955), PhD, European Commission, Directorate General for Translation, Head of the Estonian Language Department (European Commission DGT, ARIA 00 / B040, L-2920, Luxembourg); Visiting Professor at the University of Tartu (Law); heiki.pisuke@ec.europa.eu 